Int. J. Dev. Biol. 49: 851-858 (2005)

doi: $10.1387 / \mathrm{ijdb} .052013 \mathrm{ad}$

Original Article

\title{
PBX1 intracellular localization is independent of MEIS1 in epithelial cells of the developing female genital tract
}

\author{
AGNĖS DINTILHAC ${ }^{1 \#, ~ R E ́ J A N E ~ B I H A N ~}{ }^{1 \#, ~ D A N I E L ~ G U E R R I E R ~}{ }^{1}$, STÉPHANE DESCHAMPS ${ }^{1}$, HÉLOISE BOUGERIE ${ }^{1}$, \\ TANGUY WATRIN1', GEORGETTE BONNEC ${ }^{2}$ and ISABELLE PELLERIN*,1 \\ 1 UMR 6061, Génétique et Développement, IFR 140, Université de Rennes 1, Campus Villejean, Rennes, France and \\ 2 UMR 6026, Interactions Cellulaires et Moléculaires, IFR 140, Campus Beaulieu, Rennes, France
}

\begin{abstract}
While studies have highlighted the role of HOXA9-13 and PBX1 homeobox genes during the development of the female genital tract, the molecular mechanisms triggered by these genes are incompletely elucidated. In several developmental pathways, PBX1 binds to MEINOX family members in the cytoplasm to be imported into the nucleus where they associate with HOX proteins to form a higher complex that modulates gene expression. This concept has been challenged by a recent report showing that in some cell cultures, PBX1 nuclear localization might be regulated independently of MEINOX proteins (Kilstrup-Nielsen et al., 2003). Our work gives the first illustration of this alternative mechanism in an organogenesis process. Indeed, we show that PBX1 is mostly cytoplasmic in epithelial endometrial cells of the developing female genital tract despite the nuclear localization of MEIS1. We thus provide evidence for a control of PBX1 intracellular distribution which is independent of MEINOX proteins, but is cell cycle correlated.
\end{abstract}

KEY WORDS: PBX, HOXA, MEIS, Abd-B, female genital tract, mouse, cell cycle

\section{Introduction}

The mammalian female reproductive tract is derived from the Müllerian ducts that develop in a cranial to caudal direction into oviducts, uterine horns, cervix and the anterior vagina. The murine female reproductive tract is still rudimentary at birth and consists of two tubes of simple columnar epithelia surrounded by a mesenchymal sheath fused at the level of the cervix. Uterine horns develop postnatally to form an external myometrium surrounding the mesenchymal compartment that contains epithelial glands whereas the vagina and cervix do not develop glands and the luminal epithelium undergoes a transition from simple columnar to squamous morphology. The maturation of the female reproductive tract is completed 2 weeks after birth.

Loss of function experiments as well as genetic information from human disorders have highlighted the pivotal role of HOXA genes in the development of female genital tract (for review see Taylor, 2000). Indeed, positional identity along the proximo-distal axis of Müllerian ducts is given by members of the $A b d o m i n a l-B$ $(A b d-B)$ like $H O X$ gene family. $A b d-B H O X A 9$ to 13 and $H O X D 9$ to 13 genes exhibit nested, overlapping boundaries of expression that define a specific HOX code within the developing reproductive tract (Dolle et al., 1991; Taylor et al., 1997; Ma et al., 1998).
In mice, inactivation of HOXA10, HOXA11, HOXA13 and HOXD13 genes produce morphological defects along the proximodistal axis of the female reproductive tract. Moreover, one human syndrome, the Hand-Foot-Genital Syndrome (HFGS) characterized by small hands and feet and Müllerian ducts fusion defect, was shown to result from mutations in the HOXA13 gene (Mortlock and Innis 1997; Goodman et al., 2000).

HOX genes are key regulators that determine the patterning and segment identity along the anterior-posterior axis of the skeleton and a variety of organ systems (for a review see Hombria and Lovegrove, 2003). All HOX genes share a DNA sequence, the homeobox which encodes a 60 amino acid DNA binding motif referred to as the homeodomain. Proteins containing this domain are transcription factors that control the transcription of their target genes. Since the homeodomain is highly conserved amongst HOX proteins, these transcription factors share similar DNA binding specificities in vitro. A major question concerning the activity of HOX proteins is then how they regulate in vivo transcription with such a high biological specificity. This fact gave rise to the idea that specific cofactors cooperate with HOX proteins

Abbreviations used in this paper: $\mathrm{PBX}$, pre B-cell leukemia transcription factor; MEIS; myeloïd ecotropic viral integration site.

\footnotetext{
*Address correspondence to: Dr. Isabelle Pellerin. UMR 6061, Génétique et Développement, IFR 140, Université de Rennes 1, Campus Villejean, 2 avenue du Professeur Léon Bernard, CS34317, F-35043 Rennes Cedex, France. Fax: (33)-2-2323-4478. e-mail: isabelle.pellerin@univ-rennes1.fr
}

\# Note: Both authors equally contributed to this study.

$0214-6282 / 2005 / \$ 25.00$

(1) UBC Press

Printed in Spain

www.intjdevbiol.com 
and contribute to modulate DNA binding specificity. Indeed, it has been reported, using several approaches, that part of the increased binding specificity of HOX proteins in vivo comes from their interaction with members of the TALE class of homeodomain proteins that comprise PBC group (mammalian PBX proteins, Drosophila Extradenticle or EXD and Caenorhabditis elegans Ceh-20) and the MEIS-like TALE factors or MEINOX group (mammalian MEIS and PREP1 proteins, Drosophila Homothorax or HTH) (Shanmugam et al., 1999; Shen et al., 1999). In fact, PBC and MEINOX proteins are now considered as essential cofactors forming heterotrimeric complexes with $\mathrm{HOX}$ proteins that regulate specific target gene transcription. Therefore, the execution of some major developmental programs depends on the presence of HOX/PBX/MEIS complexes in the nucleus.

The sub-cellular localization of PBX proteins is highly regulated and it has been well demonstrated, in several cell backgrounds, that the binding of PBX with MEIS induces the translocation of the complex into the nucleus where it can associate with HOX proteins and then regulate target genes. This concept has been challenged by a recent report showing that in some cell cultures, PBX nuclear localization is regulated independently of MEINOX proteins by PKA phosphorylation (KilstrupNielsen et al., 2003).

While the nuclear localization of HOX and MEIS proteins in prepubertal female genital tract has been recently reported (Williams et al., 2005), the intracellular distribution of PBX1 in this model is still unknown. In this work, we show that the intracellular distribution of PBX1 is not correlated with the localization of MEIS. Indeed, PBX1 is present in the cytoplasm of luminal and glandular epithelium of immature female genital tract whereas HOX and MEIS proteins are nuclear. We thus show for the first time that the novel mechanism that has been demonstrated by Kilstrup-Nielsen (2003) is occurring in a developmental model like the developing genital tract. Indeed, this is the first illustration of a MEIS1 independent control of PBX1 intracellular distribution in a developmental pathway. Using well differentiated endometrial adenocarcinoma cell lines, we further demonstrate that PBX1 sub-cellular localization is dependant of the cell cycle. We propose that PBX1 distribution might play a role in maintaining the balance between proliferation and differentiation of epithelial endometrial cells during genital tract development.

\section{Results}

\section{HOXA9-13 genes, PBX1 and MEIS1-2 genes are co-expressed} during female genital tract development

To undertake this study, we isolated Müllerian ducts-containing mesonephros (from E12 to E14), embryonic genital tracts (from $\mathrm{E} 15$ to $\mathrm{E} 18)$ and genital tracts from newborn (P0) to pubescent mice (P15). RT-PCR experiments showed that HOXA9 to 11 , $P B X 1$ and MEIS1-2 are transcribed in genital tract from E12.5 to P9 (Fig. 1) and that this expression is maintained until the onset of puberty ( 2 weeks after birth, data not shown). Moreover, the
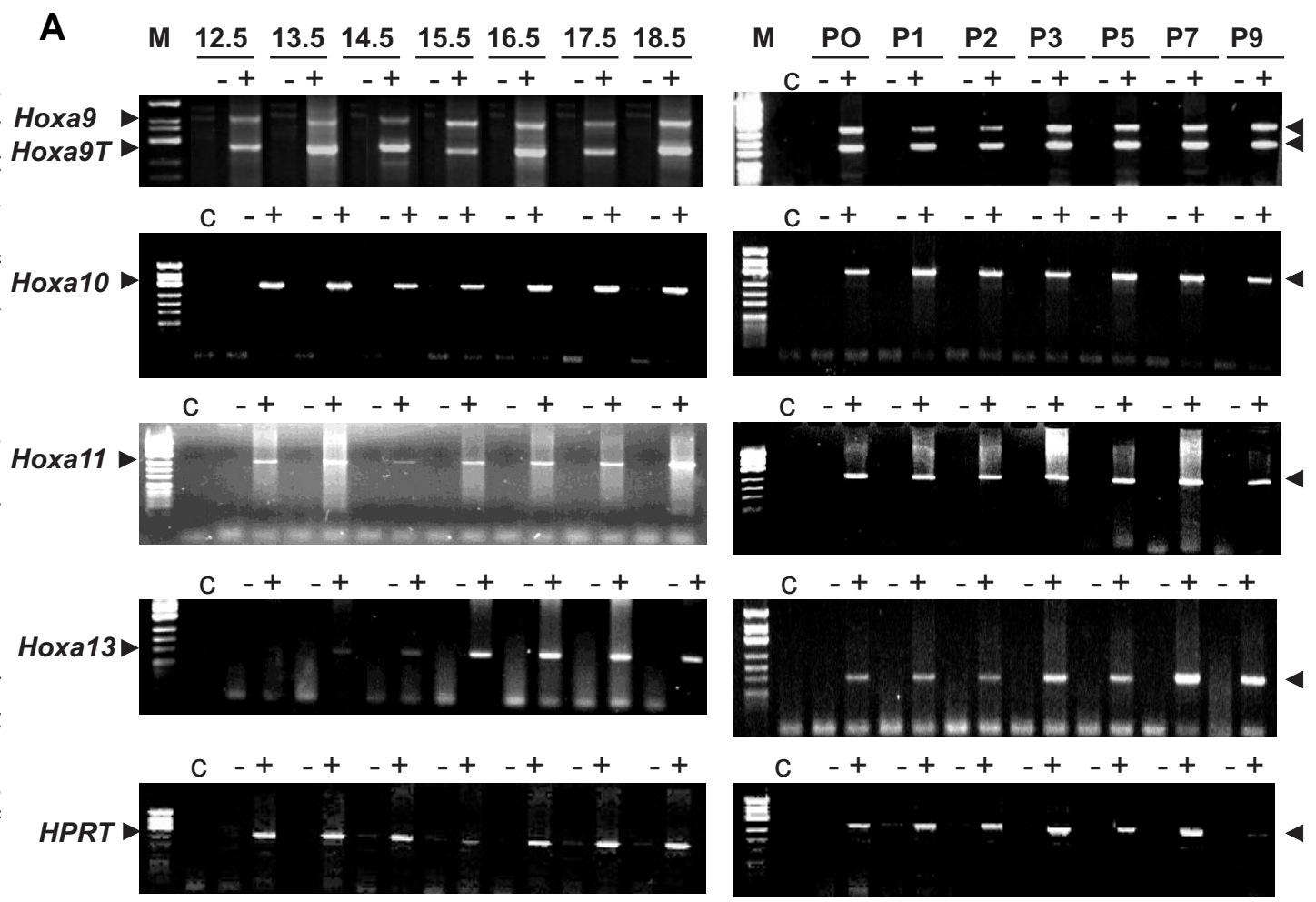

$\mathbf{B}$

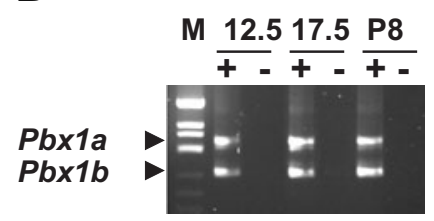

C
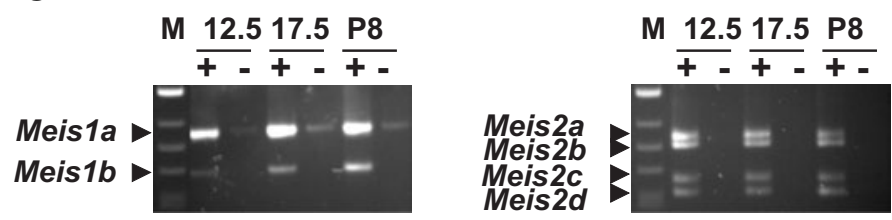

Fig. 1. HOXA9-13 (A), PBX1 (B) and MEIS1-2 (C) genes are expressed in the developing female genital tract. RT-PCR was performed on RNAs purified from embryonic and pre-pubertal genital tracts at different stages of mouse development (from E12.5 to E18.5 and from PO to P9). Reverse transcription reactions were performed with $(+)$ or without reverse transcriptase (-) and followed by PCR using appropriate primers (see Table I). A control of PCR reaction has been performed without DNA added in the reaction (track c). Amplified CDNAs were separated on 2\% agarose gel and visualized by ethidium bromide. For each experiment, an internal standard was performed with primers complementary to sequences of mouse HPRT gene. Markers (M) correspond to $\Phi X 174 /$ Hinfl (Promega). 

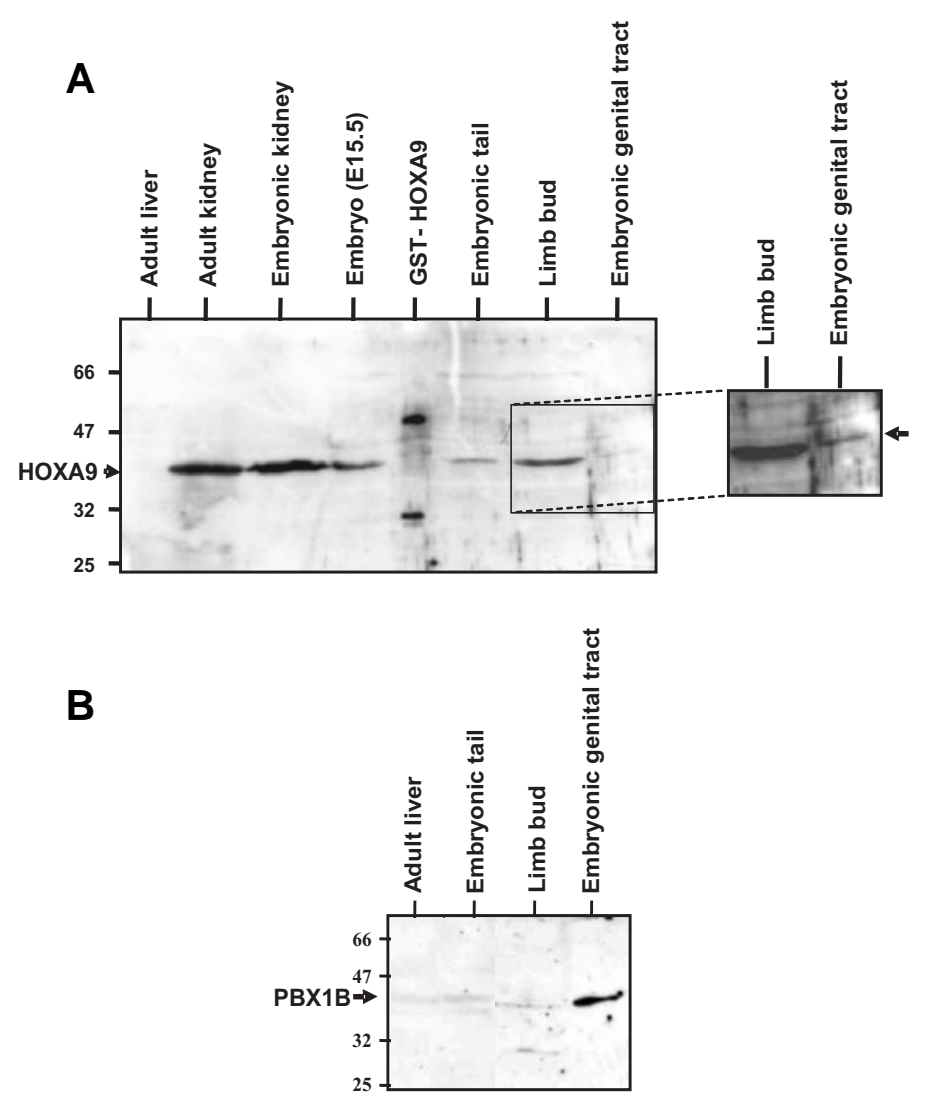

expression of $H O X A 13$ is 2 days delayed as transcripts are only detected from E14.5 in the Müllerian ducts.

As we previously observed, two HOXA9 transcripts, designated as HOXA9 and HOXA9T are present in the genital tract (Fig. 1A) throughout its development. These two alternative transcripts encode respectively for a homeodomain- and a putative non homeodomain containing protein and we have demonstrated that in the genital tract, HOXA9T is more abundant (two fold) than the typical HOXA9 homeobox containing transcript (Dintilhac et al., 2004). In addition, two transcripts corresponding to $P B X 1 A$ and
Fig. 2. HOXA9 (A) and PBX1B (B) proteins are present in the developing female genital tract. Protein extracts from embryonic (E15.5) and adult organs as well as recombinant HOXA9 (GST-HOXA9 as positive control) were loaded on SDS-PAGE, transferred onto PVDF filters and incubated with either $\alpha$-HOXA9 or $\alpha$-PBX1 antibodies. With each antibody, only one specific band is visualized and the migration of the corresponding proteins allowed us to correlate the immunoreactive band to the homeodomain containing HOXA9 protein or to the PBX1B isoform. For HOXA9 Western blot, a longer exposure of the autoradiography is shown for the last two lanes of the gel (little panel on the right). Protein markers (in $\mathrm{kDa}$ ) are indicated on the left of the blot.

$P B X 1 B$ isoforms, produced from the $P B X 1$ gene, are present in the developing genital tract (Fig. 1B). These transcripts encode for two known homeodomain proteins with different transcriptional activity (Asahara et al., 1999). In order to determine whether both isoforms of HOXA9 and PBX1 are present in the female genital tract, we performed western blots using the appropriate antibodies (see methods). Protein extracts from various embryonic (E15.5) and adult organs expressing (adult and embryonic kidney, limb bud, embryonic tail) or not (adult liver) both proteins were also analysed. We initiated the analysis of HOXA9 isoforms with a commercial antibody (Santa-Cruz) and obtained one specific band of approximately $38 \mathrm{kDa}$ in the whole embryo, adult and embryonic kidney, tail and limb bud and, to a lesser extent, in the embryonic genital tract (Fig. 2A). To confirm these results, we used other HOXA9 antibodies that recognize respectively the $\mathrm{N}$-terminal or the C-terminal region of the protein. Although these antibodies, tested in the laboratory with recombinant proteins, exhibit very high sensitivity and specificity, identical results to those obtained with the commercial antibody were observed: a very weak signal corresponding to the homeodomain containing HOXA9 protein in the female genital tract compared to a strong signal in the whole embryo, adult and embryonic kidney, tail and limb bud (data not shown). We concluded that the homeodomain containing HOXA9 protein is present in very small amount in the Müllerian ducts whereas the other isoform is either very poorly or not expressed in the embryo. Using the same protein extracts, we assessed the presence of the $P B X 1$ gene products. Although $P B X 1 A$ and $P B X 1 B$ transcripts are in apparently equal amounts (Fig $1 \mathrm{~B}$ ), only
Fig. 3. PBX1 protein is mostly present in the cytoplasm of epithelial cells of P8 female genital tract. Immunocytochemistry was performed with $\alpha$-PBX1 antibodies and a peroxidase secondary antibody. Peroxidase activity was visualized with diaminobenzidine as a chromogen. (A-D) Expression of $P B X 1$ in epithelial endometrial cells. (D) Cytoplasmic localization of PBX1 in epithelial cells. (E,F) Representative controls performed with an antibody depleted by absorption with an excess of recombinant GST-PBX1 before secondary antibody addition. Scale bars, $100 \mu \mathrm{m}$

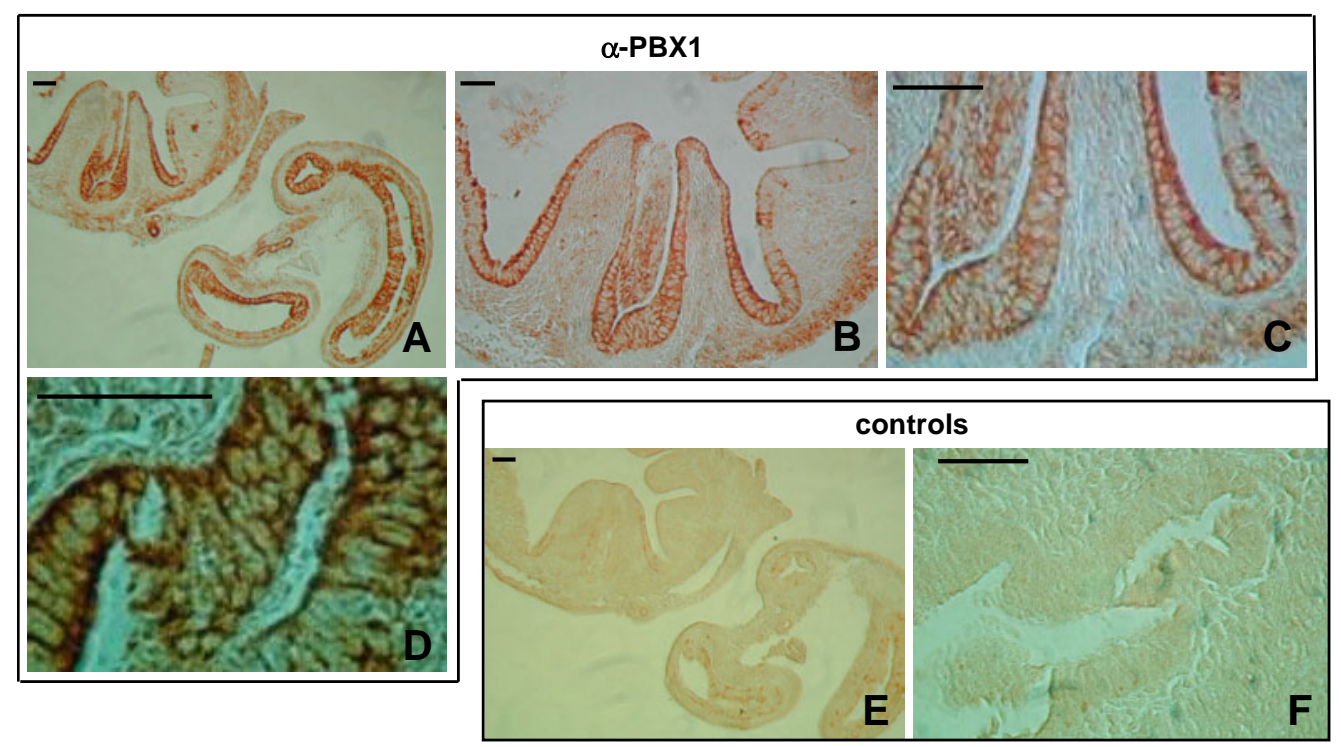


A
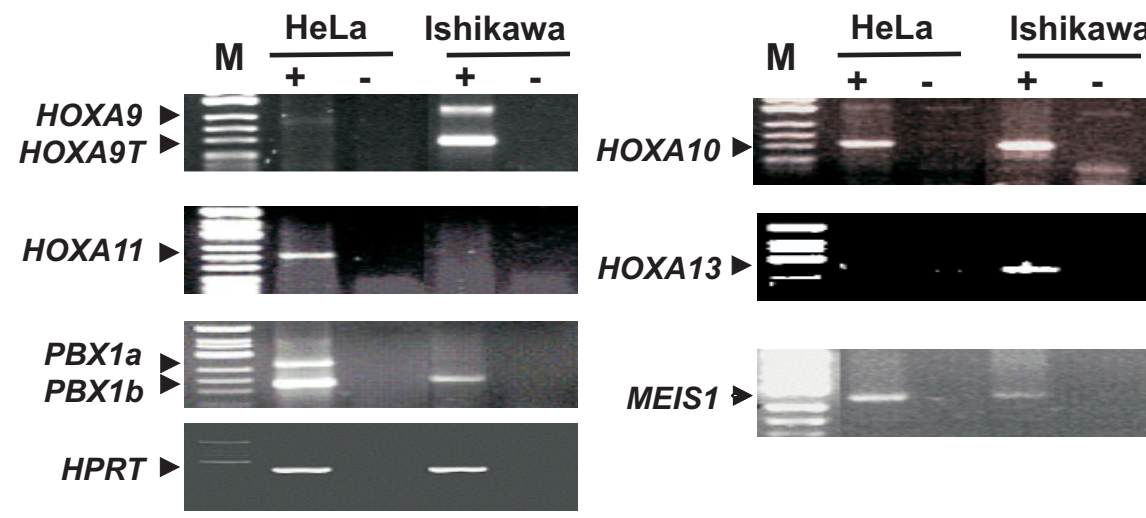

MEIS1

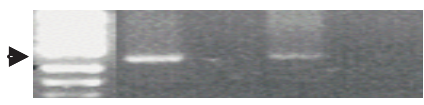

B

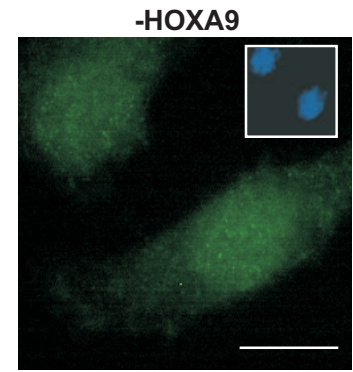

-HOXA11

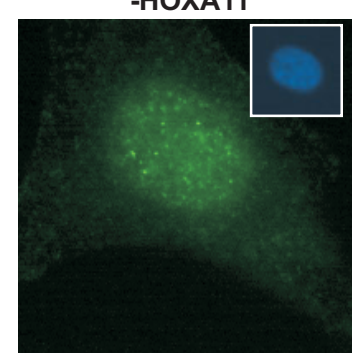

C

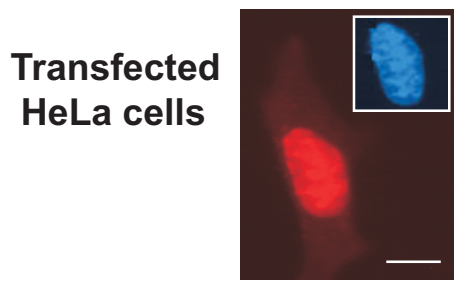

HOXA10 - Flag

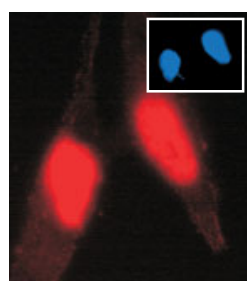

-MEIS1

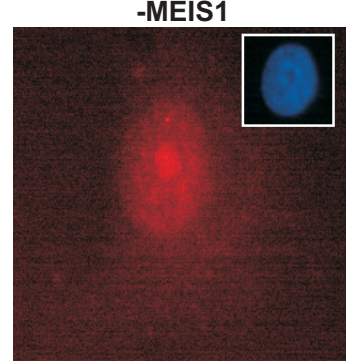

-MEIS1

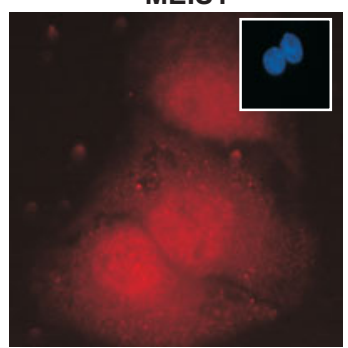

HOXA11 - Flag

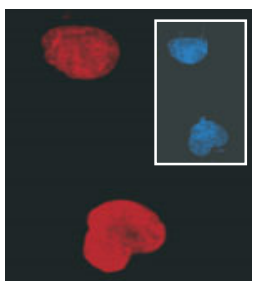

-PBX 1

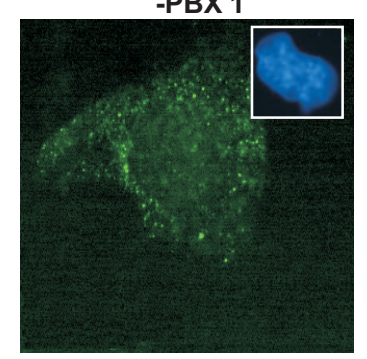

-PBX 1

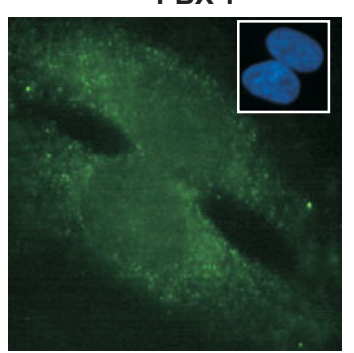

Fig. 4. Expression and localization of HOXA9-13, PBX1 and MEIS1 in HeLa and Ishikawa cells. (A) RT-PCR analysis were performed using RNA extracted from HeLa or Ishikawa cells. Reactions were performed in the presence (+) or absence of reverse transcriptase (-) and followed by PCR using appropriate primers (see Table 1). For each experiment, an internal standard was performed with primers complementary to sequences of Human HPRT gene. Markers (M) correspond to $\Phi X 174 /$ Hinfl (Promega). (B,C) Immunocytochemistry was performed on non (B) or transfected cells (C) using $\alpha$-HOXA9, $\alpha$-HOXA11, $\alpha$-PBX1, $\alpha$-MEIS1 (B) or anti Flag M2 antibodies (C). Secondary antibodies were either fluorescein or rhodamine conjugated and fluorescence was detected under UV light using a Leica microscope with a final magnification of 500X. The staining of nuclei with DAPI (b/ue) is shown in small square boxes. one immunoreactive band is observed on Western blot. A protein of around $39 \mathrm{kDa}$ corresponding to the molecular weight of the PBX1B isoform is detected in embryonic genital tract (Fig. 2B). Furthermore, the amount of this protein is higher than that detected in other PBX1B expressing embryonic organs such as limb bud or embryonic tail.

\section{PBX1B is mostly localized in the cytoplasm of immature genital tract epithelium}

According to RT-PCR experiments, HOXA9-11, PBX1 and MEIS1 transcripts are present in the mouse genital tract from embryonic day 12.5 until the onset of puberty. In order to determine the tissue localization of the translational products, we performed immunohistochemistry on P8 genital tract sections using antibodies directed against HOXA9, HOXA10, HOXA11, PBX1 and MEIS1 proteins (see methods). In accordance with Westernblot experiments, a very low immuno-staining slightly above background was observed with the three anti-HOXA9 antibodies previously described (data not shown). In contrast, a significant staining is observed with the anti-HOXA11, anti-HOXA10 and anti-MEIS1 antibodies in the nucleus of stromal and epithelial cells (data not shown). While we were working on these experiments, Williams et al., (2005) have described the distribution of HOX and MEIS1 proteins in immature female genital tract. In agreement with our results, HOX and MEIS1 proteins were clearly found in the nucleus of stromal and epithelial cells in the cervix and the vagina. The expression pattern of PBX1 has also been reported on embryonic genital tract but its distribution in prepubertal female genital tract remains unknown. As shown on Fig. 3, PBX1 is highly expressed in 
epithelial cells but is absent from the stroma of P8 immature genital tract. Furthermore, PBX1 immunostaining is mostly cytoplasmic (Fig. 3). These data demonstrate that in the P8 female genital tract, despite the presence of MEIS1 protein in the nucleus of epithelial cells, PBX1B is mostly found in the cytoplasm.

\section{MEIS proteins do not maintain PBX1 in the nucleus of Ishikawa and HeLa cells}

Since the sub-localization of MEIS1 (Williams et al., 2005) and PBX1B (this work) was intriguingly different in immature genital tract cells, we further analysed the cell distribution of these proteins using two endometrial cell lines. We studied the expression of HOXA9-13, PBX1 and MEIS1 in a well differentiated endometrial adenocarcinoma cell line, the Ishikawa cell line, in comparison with the well known cervical HeLa cell line. As a first step, we determined by RT-PCR whether the different genes were expressed in these cell lines. We observed that HOXA9, HOXA10, HOXA13 are transcribed in Ishikawa cells whereas only HOXA10 and $H O X A 11$ transcripts are present in HeLa cells (Fig. 4A). $P B X 1$ and MEIS1 genes transcripts are present in both cell lines (Fig. 4A).

We then analysed the localization of proteins by immunofluorescence using the antibodies described in methods. In both cell lines, immunostaining of HOX (HOXA9 in Ishikawa; HOXA11 in HeLa cells) and MEIS1 proteins is detected in the nucleus whereas a cytoplasmic signal is detected in most of the cells immunostained with $\alpha-P B X 1$ antibody (Fig. 4B). The same nuclear localization is observed if exogenously FLAG epitope-tagged HOXA9-10-11 proteins are expressed in HeLa cells (Fig. 4C). When over-expressed, the PBX1B protein is found in the cytoplasm but also in the nucleus cells (Fig. 4C). This is probably due to large excess of PBX1B proteins and thus to the saturation of endogenous partners involved in the nuclear/cytoplasmic regulation of $\mathrm{PBX} 1$.

\section{PBX1 sub-cellular localization is cell cycle dependent}

Intriguingly, amongst the large majority of PBX1 cytoplasmic positive HeLa or Ishikawa cells, we observed few cells showing nuclear labeling. We thus investigate whether sub-cellular distribution of PBX1 could be dependent of the cell cycle. To test this possibility, we used in double-labeling experiments with the anti-PBX1 antibody, a second antibody directed against Aurora-B which localization allowed us to determine the phases of the cell cycle. In HeLa cells, Aurora-B is absent at G1/S, starts to be detected at the end of $S$ and accumulates during $\mathrm{G} 2$. In addition, Aupresented. Scale bars, $5 \mu \mathrm{m}$.
rora-B had punctuated distribution throughout all regions of condensing chromosomes (mostly in centromeric region) from prophase to metaphase and is relocated by cytokinesis to the midbody region in telophase (Crosio et al., 2002). By comparing PBX1 and Aurora-B stainings, we can thus correlate the subcellular localization of PBX1 and the different phases of the cell cycle. As shown on Fig. 5, very low amount or no PBX1 protein is observed in the nucleus of G1 cells. Then, a signal corresponding to PBX1 appeared in the nucleus during the S-G2 phase to become predominant at the transition G2/M. These results showed clearly a link between intracellular localization of PBX1 and the stages of the cell cycle.

\section{Discussion}

In this work, we show that while HOXA9-13, $P B X 1$ and $M E / S 1$ are expressed throughout Müllerian ducts differentiation, they are not identically localized: HOX and MEIS proteins are found in the nucleus of all Müllerian derived cells whereas PBX1 is present mostly in the cytoplasm of endometrial epithelial cells. Our data strengthen recent data showing that PBX1 sub-cellular localization is regulated by mechanisms independent of MEINOX proteins (Kilstrup-Nielsen et al., 2003). Moreover, using endometrial cell line, we further demonstrate that PBX1 intracellular distribution is dependent on the stage of the cell cycle. We propose that the sub-cellular localization of PBX1 could be part of a molecular mechanism that ensures the
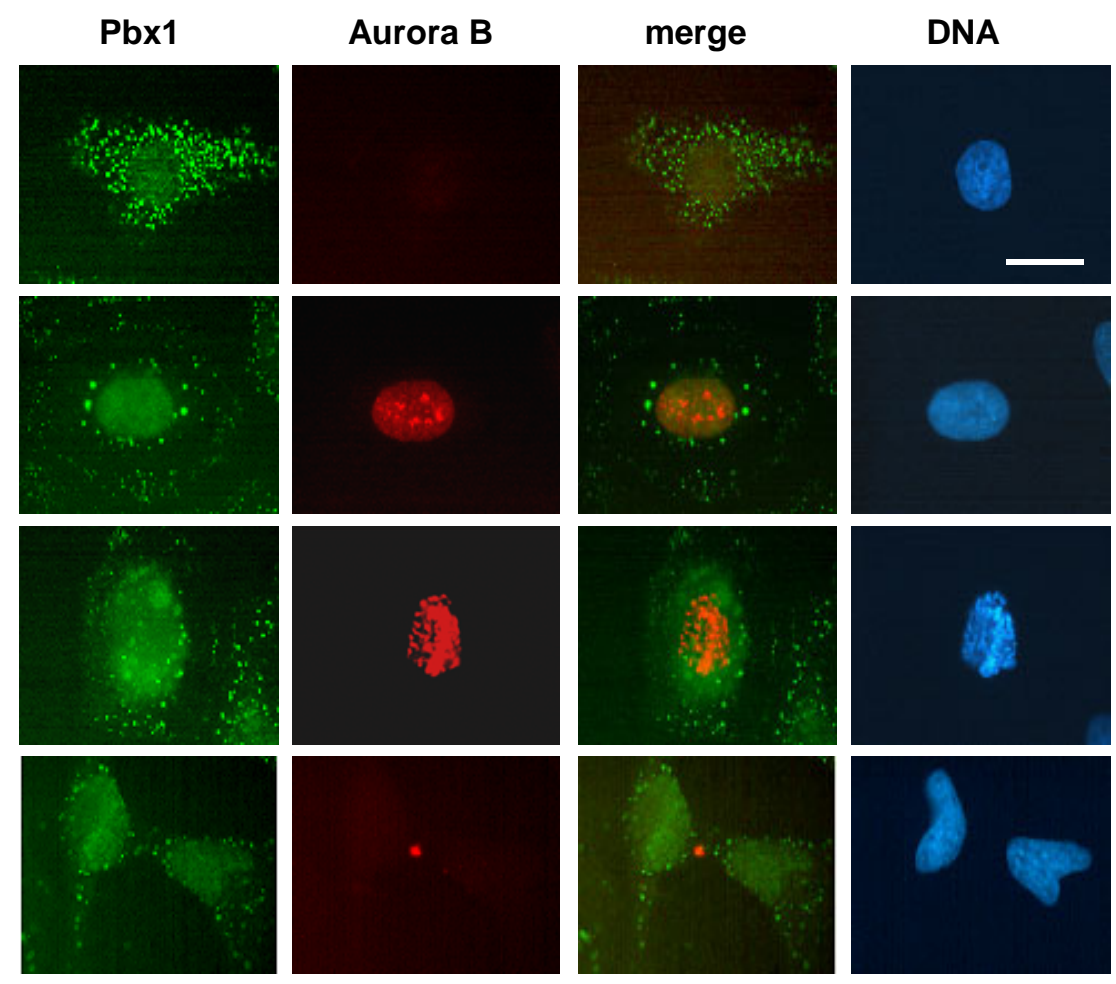

G1

G2

telophase

Fig. 5. PBX1 sub-cellular localization is cell cycle dependant. Immunocytochemistry was performed on HeLa cells by double immunostaining using $\alpha$-PBX1 and $\alpha$-Aurora-B. Secondary antibodies were either fluorescein or rhodamine conjugated and fluorescence was detected under UV light using a Leica microscope with a final magnification of 500X. The staining of nuclei with DAPI (blue) has been performed and is 
balance between proliferation and differentiation of epithelial endometrial cells.

\section{PBX1 is not co-localized with MEIS1 in epithelial endometrial cells}

The differentiation of the female genital tract is partly controlled by HOXA9-13 genes that establish a molecular code along the length of the paramesonephric ducts and specify regional identity of cells leading to the correct development of the Müllerian ducts into oviducts, uterus, cervix and a portion of the vagina (Taylor et al., 1997, 2000). More recently, the role of PBX1 in the development of the uro-genital system has been demonstrated. In $P b \times 1 \%$ mice, the Müllerian ducts are absent (Selleri etal., 2001) and a recent work has reported that PBX1 exhibited a dynamic and tissue-restricted pattern of expression throughout urogenital embryogenesis (Schnabel et al., 2003). These data suggest that both partners might cooperate to shape correctly female genital tract.

HOX genes encode homeodomain transcription factors that

\section{TABLE 1}

PCR PRIMER SEQUENCES, PRODUCT SIZES AND GENBANK ACCESSION NUMBERS

\begin{tabular}{|c|c|c|c|c|}
\hline & Primer & $\begin{array}{l}\text { Sequence of primers } \\
\left(5^{\prime} \rightarrow 3^{\prime}\right)\end{array}$ & Product size (bp) & $\begin{array}{l}\text { GenBank accession } \\
\text { number }\end{array}$ \\
\hline \multirow{8}{*}{ 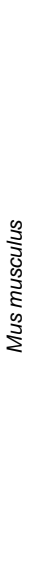 } & Ноха9/9T & $\begin{array}{l}\text { CAGTCCTTGCAGCTTCC } \\
\text { CGTCTGGTGTTTTGTGT }\end{array}$ & $505 / 332$ & NM_010456/AB005458 \\
\hline & Hoxa10 & $\begin{array}{l}\text { AGCTCGCTAGTCCCTTTCCT } \\
\text { CGCTACGGCTGATCTCTAGG }\end{array}$ & 411 & BC050839 \\
\hline & Hoxa11 & $\begin{array}{l}\text { GTTTTTCGAGACGGCTTACG } \\
\text { TATAAGGGCAGCGCTTTTTG }\end{array}$ & 317 & U20370 \\
\hline & Hoxa13 & $\begin{array}{l}\text { CCAAATGTACTGCCCCAAAG } \\
\text { CCTCCGTTTGTCCTTGGTAA }\end{array}$ & 199 & NM_008264 \\
\hline & ${ }^{\mathrm{a}} \mathrm{HPRT}$ & $\begin{array}{l}\text { CCTGCTGGATTACATTAAAGCACTG } \\
\text { GTCAAGGGCATATCCAACAACAAAC }\end{array}$ & 352 & BC004686 \\
\hline & ${ }^{\mathrm{b}} \mathrm{Pb} \times 1 \mathrm{a} / 1 \mathrm{~b}$ & $\begin{array}{l}\text { GAGTTAGCCAAGAAGTGCGG } \\
\text { TAGTAGCGTCCTGCCAACCT }\end{array}$ & $427 / 314$ & AF020196/L27453 \\
\hline & $\begin{array}{l}{ }^{c} \text { Meis } 1 \mathrm{a} / \\
1 \mathrm{~b}\end{array}$ & $\begin{array}{l}\text { CAGCACATGGGCATCAGAGCG } \\
\text { CTGTCCTCCATGCATCATCACT }\end{array}$ & $305 / 210$ & U33629/U33630 \\
\hline & $\begin{array}{l}{ }^{\mathrm{d}} \text { Meis } 2 \mathrm{a} / \\
2 \mathrm{~b} / 2 \mathrm{c} / 2 \mathrm{~d}\end{array}$ & $\begin{array}{l}\text { CCATGATTGACCAGTCAAAT } \\
\text { GACCACCCTGAGAAACGTAG }\end{array}$ & $275 / 254 / 180 / 159$ & $\begin{array}{l}\text { AJ000504/AJ000505/ } \\
\text { AJ000506/AJ000507 }\end{array}$ \\
\hline \multirow{8}{*}{ 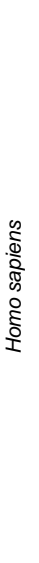 } & Ноха9/9Т & $\begin{array}{l}\text { TGTACCACCACCATCACCAC } \\
\text { ATGAAGCCAGTTGGCTGCTG }\end{array}$ & $362 / 189$ & $\begin{array}{l}\text { BT006990/ } \\
\text { NM_002142 }\end{array}$ \\
\hline & Hoxa10 & $\begin{array}{l}\text { AAGGAGCGAGCCCTCGATTC } \\
\text { GCCGTGAGCCAGTTGGCTGC }\end{array}$ & 203 & NM_018951 \\
\hline & Hoxa11 & $\begin{array}{l}\text { TTTTTCGAGACAGCCTACGG } \\
\text { CGCTTTTTGCGGGTGCGTTG }\end{array}$ & 308 & NM_005523 \\
\hline & Hoxa13 & $\begin{array}{l}\text { GCGGACAAGTACATGGATAC } \\
\text { AGCTGGCATCCGAGGGATG }\end{array}$ & 334 & NM_000522 \\
\hline & ${ }^{\mathrm{a}} \mathrm{HPRT}$ & $\begin{array}{l}\text { CCTGCTGGATTACATCAAAGCACTG } \\
\text { GTCAAGGGCATATCCTACAACAAAC }\end{array}$ & 352 & $\mathrm{BC} 000578$ \\
\hline & ${ }^{\mathrm{b}} \mathrm{Pb} \times 1 \mathrm{a} / 1 \mathrm{~b}$ & $\begin{array}{l}\text { GAGTTAGCCAAGAAGTGCGG } \\
\text { CTGATAACATGGCGAAGGGT }\end{array}$ & $335 / 222$ & M86546 \\
\hline & $\begin{array}{l}{ }^{c} \text { Meis1a/ } \\
1 \mathrm{~b}\end{array}$ & $\begin{array}{l}\text { CAACATATGGGAATTAGAGC } \\
\text { CTGTCCTCCATGCATCATCACT }\end{array}$ & $306 / 211$ & NM_002398 \\
\hline & $\begin{array}{l}{ }^{\mathrm{d}} \text { Meis2a/ } \\
2 \mathrm{~b} / 2 \mathrm{C} / 2 \mathrm{~d}\end{array}$ & $\begin{array}{l}\text { CCATGATTGACCAGTCAAAT } \\
\text { GACCACCCTGAGAAACGTAG }\end{array}$ & 276/255/180/159 & $\begin{array}{l}\text { AF178948/NM_170674/ } \\
\text { NM_170675/NM_170676 }\end{array}$ \\
\hline
\end{tabular}

aHPRT: hypoxanthine guanine phosphoribosyl transferase

bPbx1a/1b: pre B-cell leukemia transcription factor 1, transcript variant a and b respectively

${ }^{c}$ Meis $1 \mathrm{a} / 1 \mathrm{~b}$ : myeloid ecotropic viral integration site 1 , transcript variant a and b respectively

${ }^{\mathrm{d}}$ Meis2a/2b/2c/2d: myeloid ecotropic viral integration site 2, transcript variant a, b, c, and d respectively recognize very similar core DNA sequences (TAAT) and this property contrasts with their high specific biological functions. HOX transcription factors gain specificity by forming complexes with proteins of the PBC group. Indeed, HOX/PBC proteins recognize a larger motif (TGATNNAT) where the identity of the NN nucleotides determines the preferential binding of a particular HOX protein. Thus, HOX proteins regulate different genetic programs in the presence or in the absence of $\mathrm{PBC}$ proteins in the nucleus of cells. Interestingly, the subcellular localization of PBC proteins is highly regulated in several cell contexts (Vogt and Duboule, 1999). Recently, Villaescusa et al. (2004) showed nuclear-cytoplasmic regulation of PREP-1/PBX1 in the adult mouse oocyte.

The nuclear export of $\mathrm{PBX} 1$ requires a signal located within the PBC-A domain of the protein and is prevented by heterodimerization with MEINOX proteins PREP1 and HTH (Saleh etal., 2000; Berthelsen etal., 1999). Thus, in cells that co-express PBX1 and MEINOX proteins, the two partners heterodimerize and the complex is retained in the nucleus. In the present work, we showed that despite the presence of MEIS1, PBX1 is cytoplasmic in P8 genital tract and in endometrial cell lines.

Recently, Kilstrup-Nielsen etal. (2003) demonstrated that PBX1 can be imported or exported from the nucleus independently of its capacity to interact with MEINOX proteins. Indeed, in some cell cultures, PBX1 subcellular localization correlates with the phosphorylation state of Ser/Thr residues whose dephosphorylation induces nuclear export. In addition, Huang et al. (2003) identified a novel PBX1 partner corresponding to a non muscle myosin protein that is able to regulate PBX1 sublocalization. These reports show that additional levels of PBX1 localization control occur independently of MEINOX proteins. In our work, we demonstrated that in endometrial cells, PBX1 is cytoplasmic even with co-expression of MEIS1, suggesting that the presence of this partner is not sufficient to prevent PBX1 nuclear export. We thus showed, in a particular developmental pathway such as the developing female genital tract, the existence of this MEIS independent molecular mechanism that controls intracellular distribution of PBX1.

\section{PBC sub-cellular localization and organo- genesis}

In Drosophila, HTH is required for the nuclear translocation of EXD. EXD is expressed in both proximal and distal regions of the leg imaginal discs, but nuclear EXD is only found in the proximal region where HTH is coexpressed (Abu-Shaar et al., 1998; Gonzales-Crespo et al., 1998). The control of PBC protein activity through sub-cellular localization is an evolutionary conserved mechanism and mammalian MEIS1 and PREP1 can substitute for fly $\mathrm{HTH}$ to induce EXD nuclear translocation in 
both cell culture and Drosophila embryo (Rieckhof et al., 1997; Abu-Shaar et al., 1999; Berthelsen et al., 1999. The mammal embryonic female genital tract represents a developmental axis similar to appendicular or skeletal axis which forms according to a HOX code (Taylor-et al., 1997; 2000). It develops as a specialization of the paramesonephric ducts which gives rise to oviducts, uterus and anterior vagina. Our data and others (Williams et al., 2005) show that MEIS1 is also co-expressed with PBX1 in the developing Müllerian ducts and might therefore also be involved in this organogenesis. However, in contrast to other developmental models such as the limb bud, the presence of MEIS1 is not sufficient to induce PBX1 nuclear localization and other or additional molecular mechanisms are probably involved.

\section{PBX1 nuclear translocation precedes mitosis}

Several data have reported the involvement of PBX1 in cell proliferation (Schnabel et al., 2001; Dutta et al., 2001) while others suggest a role in cell fate determination in a variety of tissues that depend on mesenchymal-epithelial interactions for their coordinated morphogenesis (Roberts et al., 1995; Warburton et al., 2000). Indeed, PBX1 contributes to various cellular processes during embryogenesis including cell autonomous regulation as well as mediation of tissue interaction (Schnabel et al., 2001). How PBX1 triggers these multiple cell processes during development remains unclear.

Morphogenetic events that permit mammalian uteri development include 1) organization and stratification of endometrial stroma 2) differentiation and growth of the myometrium and 3) coordinated development of the endometrial glands or adenogenesis. The third event occurs postnatally and involves differentiation of glandular epithelium from the luminal epithelium and then development of this glandular epithelium. Thus, the prepubertal female genital tract achieves its maturation after birth by adenogenesis which requires differentiation, migration and proliferation of endometrial cells. Our experiments have demonstrated that PBX1 distribution is dependant upon the cell cycle phases. Indeed, while no or low amount of PBX1 is detected in the nucleus of G1-S cells, the protein is translocated into the nucleus during the $\mathrm{G} 2$ phase. PBX1 intracellular distribution is thus correlated to cell cycle phases in endometrial cultured cells. We propose that during adenogenesis the same nuclear/cytoplasmic regulation could take place and play a role in the coordination between cell proliferation and differentiation of endometrial cells. This attractive hypothesis will have now to be tested.

\section{Materials and Methods}

\section{Antibodies}

Antibodies used were either generated in rabbits for the laboratory by Eurogentec or commercially available from Santa-Cruz or Sigma. Anti HOXA9 antibodies were either generated against the peptide: LGAGRYAPGTLGQPPR (rabbit polyclonal antibody designated $\alpha$ HOXA9N, Eurogentec) or against the peptide: PPVDREKQPSEGAFS (rabbit polyclonal antibody designated $\alpha$-HOXA9C, Eurogentec) or the $\alpha$ HOXA9 commercial (N-20, sc-17155, goat polyclonal antibody, SantaCruz). The anti HOXA10 antibody was the $\alpha$-HOXA10 (A-20, sc-17159, goat polyclonal antibody, Santa-Cruz). The anti HOXA11 was generated against the peptide: NLASSDYPGDKNAEK (rabbit polyclonal antibody designated $\alpha$-HOXA11, Eurogentec). The anti PBX1 antibody corresponded to the $\alpha-P B X 1$ (P-20, sc-889, rabbit polyclonal antibody, Santa-Cruz), the anti MEIS antibody to the $\alpha$-MEIS1 (C-17, sc-10599, goat polyclonal antibody, Santa-Cruz) and the anti aurora-B antibody to the AIM-1 (611082, mouse monoclonal antibody, BD Biosciences). The FLAG antibody was obtained from Sigma (anti FLAG M2 monoclonal antibody).

\section{Reverse Transcriptase-Polymerase Chain Reaction}

Total RNAs were extracted from female genital tracts dissected from Swiss mice (from embryonic day 12.5, E12.5 to postnatal day 15, P15), HeLa or Ishikawa cells using the RNeasy kit (Qiagen). Then, cDNA synthesis was performed at $37^{\circ} \mathrm{C}$ for $1-2 \mathrm{~h}$ using $500 \mathrm{ng}$ of total cellular RNA, random hexamer primers (New England Biolabs) and 200 units of MMLV reverse transcriptase (Invitrogen). All reactions were performed in parallel in the absence of reverse transcriptase (control, RT-). PCR reactions were performed using the primers listed in Table I. PCR conditions were $94^{\circ} \mathrm{C}$ for $45 \mathrm{~s}$, annealing for $45 \mathrm{~s}$ at temperatures decreasing from 69 to $50^{\circ} \mathrm{C}$ during the first 20 cycles (with $1^{\circ} \mathrm{C}$ decremental step in each cycle) and for $50^{\circ} \mathrm{C}$ during 20 following cycles. PCR reactions were completed by a final extension at $72^{\circ} \mathrm{C}$ for 10 minutes. As a control for total RNA integrity, Hypoxanthine Guanine Phosphoribosyl Transferase (HPRT) RT-PCR experiments were performed systematically on each sample. The resulting products were analyzed on an ethidium bromide-stained $2 \%$ agarose gel.

\section{Protein extracts and Western blot analysis}

Mouse female embryos (E15.5) were dissected to prepare, tails, limb buds, kidneys and genital tracts. Livers and kidneys were also isolated from adult mouse. Tissues were frozen and stored at $-80^{\circ} \mathrm{C}$. About one $\mathrm{g}$ of each tissue was washed several times in $0.9 \% \mathrm{NaCl}$ and homogenized in lysis buffer (20mM Hepes, pH 7.9; 1.5mM MgCl2; 0.2mM EDTA; 1mM DTT; $0.2 \%$ NP- $40 ; 25 \%$ glycerol) containing a mix of proteases inhibitors (Sigma). Mechanical lysis was performed at $4^{\circ} \mathrm{C}$ using a Polytron PT1600E (Bioblock). Extracts were filtered and $\mathrm{NaCl}$ was added to adjust concentration to $0.4 \mathrm{M}$. Extracts were kept $30 \mathrm{~min}$ at $4^{\circ} \mathrm{C}$, centrifuged $30 \mathrm{~min}(2000 \mathrm{~g}$, $4^{\circ} \mathrm{C}$ ) and supernatants were recovered. Aliquots were stored at $-20^{\circ} \mathrm{C}$. Proteins $(100 \mu \mathrm{g})$ were separated on SDS-polyacrylamide gel and electrotransferred onto PVDF membrane (Immobilon). Western-blots were performed using $\alpha$-HOXA9, $\alpha$-HOXA9N, $\alpha$-HOXA9C or $\alpha-P B X 1$ antibodies.

\section{Immunohistochemistry}

Genital tracts from 8 days old female mice (P8), previously fixed in MEMFA (0.1M MOPS pH 7.4; 2mM EGTA; $1 \mathrm{mM} \mathrm{MgSO} 4 ; 3.7 \%$ Formaldehyde) buffer for 2 hours, were paraffin embedded for subsequent immunohistochemical localization of HOXA-9 to -11 , PBX1 and MEIS1 proteins. Serial sections $(7 \mu \mathrm{m})$ were deparaffined in histosol, progressively rehydrated, washed in water followed by PBS and treated with $3 \%$ hydrogen peroxide in methanol for $30 \mathrm{~min}$. in order to inhibit endogenous peroxidase activity. When $\alpha$-HOXA9N, $\alpha$-HOXA9C, $\alpha$-HOXA10 and $\alpha$-PBX 1 antibodies were used, immunohistochemical staining was performed following instructions of the Vectastain Elite ABC kit (Vector Laboratories). For $\alpha$ HOXA9, $\alpha$-HOXA10 and $\alpha$-MEIS1 experiments were done without this amplification system. Secondary antibodies were visualized using diaminobenzidine (Sigma) as a chromogen. Sections were dehydrated and mounted in permanent Entellan medium. Control experiments were performed using either antibodies depleted by absorption with an excess of recombinant GST-HOXA11 or GST-HOXA9 proteins (immunohistochemistry performed with $\alpha$-HOXA9 and $\alpha$-HOXA11 antibodies) or with nonimmune serum (immunohistochemistry performed with $\alpha$-HOXA10, $\alpha$ PBX1 and $\alpha$-MEIS1).

\section{Immunocytochemistry}

HeLa and Ishikawa cells were seeded onto microscope cover slips in a 12 -well plate and grown for $24 \mathrm{~h}$ to $60-70 \%$ confluence in DMEM supplemented with $10 \% \mathrm{FCS}$ in $5 \% \mathrm{CO} 2$ at $37^{\circ} \mathrm{C}$. Using the TransFastTM transfection Reagent (Promega), HeLa cells were transfected with $1 \mu \mathrm{g}$ of plasmid DNA encoding for HOXA9-FLAG, HOXA10-FLAG, HOXA11- 
FLAG or PBX1B-FLAG and grown for another 24 hours as described above. Transfected or non-transfected cells were then fixed with PBSFormaldehyde $3.7 \%(\mathrm{v} / \mathrm{v})$ for $30 \mathrm{~min}$ at room temperature and submitted to immunocytochemistry as previously described (Roghi et al., 1998) using as primary specific antibodies $\alpha$-HOXA9N, $\alpha$-HOXA11, $\alpha$-PBX1, $\alpha$-MEIS $1, \alpha$ Aurora-B and FLAG M2 monoclonal antibody (Sigma). Cells were then incubated with fluorescein conjugated goat anti-rabbit lgG (FITC-lgGg, Jackson) or rhodamine conjugated mouse anti-goat IgG (TRITC-IgGm, Jackson) or rhodamine conjugated goat anti-mouse IgG (TRITC-lgGg, Jackson). Controls were performed using either antibodies depleted by absorption with an excess of recombinant GST-HOXA9, GST-HOXA11 or GST-PBX1B proteins (immunocytochemistry performed with $\alpha$-HOXA9N, $\alpha$-HOXA11, $\alpha$-PBX1) or by omitting primary antibodies (immunocytochemistry performed with $\alpha$-MEIS1, $\alpha$-Aurora-B, anti FLAG M2). Immunofluorescence was observed using a LEICA DM-RXA fluorescence microscope and images collected with a charge-coupled device camera.

\section{Acknowledgements \\ IP wishes to thank sincerely people who provide us with vectors (Dr. C. Largman, Dr. M. Cleary). We are gratefulto A. Burelfortechnical assistance and to Stéphanie Dutertre from the microscopy platform of IFR 140. We are also indebted to Dr. F. Omilli, Dr. B. Osborne and Dr. C. Prigent for helpful comments on the manuscript. $A D$ and $H B$ were supported by a grant from the "Conseil Régional de Bretagne". This work was supported by the CNRS and by grants from "Rennes Métropole" and the "Conseil Régional de Bretagne" and "La Fondation Langlois".}

\section{References}

ABU-SHAAR, M. and MANN, R.S. (1998). Generation of multiple antagonistic domains along the proximodistal axis during Drosophila leg development. Deve/opment 125: 3821-3830.

ABU-SHAAR, M, RYOO, H.D. and MANN, R.S. (1999). Control of the nuclear localization of Extradenticle by competing nuclear import and export signals. Genes Dev. 13: 935-945.

ASAHARA, H., DUTTA, S., KAO, H.Y., EVANS, R.M. and MONTMINY, M. (1999). $\mathrm{Pbx}$-Hox heterodimers recruit coactivator-corepressor complexes in an isoformspecific manner. Mol Cell Biol. 19: 8219-8225.

BERTHELSEN, J., KILSTRUP-NIELSEN, C., BLASI, F., MAVILIO, F. and ZAPPAVIGNA, V. (1999). The subcellular localization of PBX1 and EXD proteins depends on nuclear import and export signals and is modulated by association with PREP1 and HTH. Genes Dev. 13: 946-953.

CROSIO, C., FIMIA, G.M., LOURY, R., KIMURA, M., OKANO, Y., ZHOU, H., SEN, S., ALLIS, C.D. and SASSONE-CORSI, P. (2002). Mitotic phosphorylation of histone H3: spatio-temporal regulation by mammalian Aurora kinases. Mo/ Cel/ Biol. 22: 874-885.

DINTILHAC, A., BIHAN, R., GUERRIER, D., DESCHAMPS, S. and PELLERIN, I. (2004). A conserved non-homeodomain HOXA9 isoform interacting with CBP is co-expressed with the «typical» HOXA9 protein during embryogenesis. Gene Expression Pattern 4: 215-222.

DOLLE, P., IZPISUA-BELMONTE, J.C., BROWN, J.M., TICKLE, C. and DUBOULE, D. (1991). HOX-4 genes and the morphogenesis of mammalian genitalia. Genes Dev. 10: 1767-1767.

DUTTA, S., GANNON, M., PEERS, B., WRIGHT, C., BONNER-WEIR, S. and MONTMINY, M. (2001). PDX:PBX complexes are required for normal proliferation of pancreatic cells during development. Proc Nat/ Acad Sci USA. 98: 1065-1070.

HUANG, H., PALIOURAS, M., RAMBALDI, I., LASKO, P. and FEATHERSTONE M. (2003). Nonmuscle myosin promotes cytoplasmic localization of PBX. Mol Cell Biol. 10: 3636-3645.

GONZALEZ-CRESPO, S., ABU-SHAAR, M., TORRES, M., MARTINEZ-A, C., MANN, R.S. and MORATA, G. (1998). Antagonism between extradenticle function and Hedgehog signalling in the developing limb. Nature 394:196-200.

GOODMAN, F.R., BACCHELLI, C., BRADY, A.F., BRUETON, L.A., FRYNS, J.P.,
MORTLOCK, D.P., INNIS, J.W., HOLMES, L.B., DONNENFELD, A.E., FEINGOLD, M., BEEMER, F.A., HENNEKAM, R.C. and SCAMBLER, P.J. (2000). Novel HOXA13 mutations and the phenotypic spectrum of hand-foot-genital syndrome. Am J Hum Genet. 67: 197-202.

HOMBRIA, J.C. and LOVEGROVE, B. (2003). Beyond homeosis-HOX function in morphogenesis and organogenesis. Differentiation 71: 461-476.

KILSTRUP-NIELSEN, C., ALESSIO, M. AND ZAPPAVIGNA, V. (2003). PBX1 nuclear export is regulated independently of PBX-MEINOX interaction by PKA phosphorylation of the PBC-B domain. EMBO J. 22: 89-99.

MA, L., BENSON, G.V., LIM, H., DEY, S.K. and MAAS, R.L. (1998). Abdominal B (AbdB) Hoxa genes: regulation in adult uterus by estrogen and progesterone and repression in mullerian duct by the synthetic estrogen diethylstilbestrol (DES). Dev Biol. 197:141-154

MORTLOCK, D.P. and INNIS, J.W. (1997). Mutation of HOXA13 in hand-foot-genital syndrome. Nat Genet. 15: 179-180.

RIECKHOF, G.E., CASARES, F., RYOO, H.D., ABU-SHAAR, M. and MANN, R.S. (1997). Nuclear translocation of extradenticle requires homothorax, which encodes an extradenticle-related homeodomain protein. Cell 91: 171-183.

ROBERTS, V.J., VAN DIJK, M.A. and MURRE, C. (1995). Localization of Pbx1 transcripts in developing rat embryos. Mech Dev. 51: 193-198.

ROGHI, C., GIET, R., UZBEKOV, R., MORIN, N., CHARTRAIN, I., LE GUELLEC, R., COUTURIER, A., DOREE, M., PHILIPPE, M. and PRIGENT, C. (1998). The Xenopus protein kinase $\mathrm{pEg} 2$ associates with the centrosome in a cell cycledependent manner, binds to the spindle microtubules and is involved in bipolar mitotic spindle assembly. J Cel/ Sci. 111: 557-572.

SALEH, M., HUANG, H., GREEN, N.C. and FEATHERSTONE, M.S. (2000). A conformational change in PBX1A is necessary for its nuclear localization. Exp Cell Res. 260: 105-115.

SCHNABEL, C.A., SELLERI, L., JACOBS, Y., WARNKE, R. and CLEARY, M.L. (2001). Expression of PBX1B during mammalian organogenesis. Mech Dev. 100: 131-135.

SCHNABEL, C.A, SELLERI, L. and CLEARY, M.L. (2003). PBX1 is essential for adrenal development and urogenital differentiation. Genesis 37: 123-130.

SELLERI, L., DEPEW, M.J, JACOBS, Y., CHANDA, S.K, TSANG, K.Y, CHEAH, K.S, RUBENSTEIN, J.L, O'GORMAN, S. and CLEARY, M.L. (2001). Requirement for PBX1 in skeletal patterning and programming chondrocyte proliferation and differentiation. Development 128: 3543-3557.

ShaNmugam, K., GREEN, N.C., RAMBALDI, I., SARAGOVI, H.U. and FEATHERSTONE, M.S. (1999). PBX and MEIS as non-DNA-binding partners in trimeric complexes with HOX proteins. Mol Cell Biol. 19: 7577-7588.

SHEN, W.F, ROZENFELD, S., KWONG, A., KOM VES, L.G., LAWRENCE, H.J and LARGMAN, C. (1999). HOXA9 forms triple complexes with PBX2 and MEIS1 in myeloid cells. Mol Cel/ Biol. 19: 3051-3061.

TAYLOR, H.S., VANDEN HEUVEL, G.B. and IGARASHI, P., (1997). A conserved Hox axis in the mouse and human female reproductive system: late establishment and persistent adult expression of the Hoxa cluster genes. Biol. Reprod. 57: 13381345.

TAYLOR, H.S., (2000). The role of HOX genes in the development and function of the female reproductive tract. Semin. Reprod. Med. 18: 81-89.

VILLAESCUSA, J.C., VERROTTI, A.C., FERRETTI, E., FAROOKHI, R. and BLASI, F. (2004). Expression of Hox cofactor genes during mouse ovarian follicular development and oocyte maturation. Gene. 14: 1-7.

VOGT, T.F. and DUBOULE, D. (1999). Antagonists go out on a limb. Cel/99:563-566.

WARBURTON, D., SCHWARZ, M., TEFFT, D., FLORES-DELGADO, G. ANDERSON, K.D. and CARDOSO, W.V. (2000). The molecular basis of lung morphogenesis. Mech Dev. 92: 55-81.

WILLIAMS, T.M., WILLIAMS, M.E. and INNIS, J.W. (2005). Range of HOX/TALE superclass associations and protein domain requirements for HOXA13: MEIS interaction. Dev Biol. 277: 457-471.

Received: April 2005

Reviewed by Referees: May 2005

Modified by Authors and Accepted for Publication: June 2005 